\title{
Urea decomposition activities in an ammonium enriched freshwater pond
}

\author{
Myung Gil Park, Jae Hyung Shim, Byung Cheol Cho* \\ Department of Oceanography and Research Institute of Oceanography, Seoul National University, Shin-lim Dong, \\ Kwan-ak Gu, Seoul 151-742, Republic of Korea
}

\begin{abstract}
Urea decomposition activities, urea and ammonium concentrations, and the concentration of chlorophyll a (chl a) were measured in an ammonium enriched, hypertrophic freshwater pond at 5 to $7 \mathrm{~h}$ intervals during 3 diel cycles on June 27 to 28, September 6 to 7, 1992 and February 14 to 15, 1993. The study site was characterized by very high ammonium concentrations, ranging from 123.6 to $403.6 \mu \mathrm{M}$. During the study period, the urea concentration ranged from 1.3 to $9.1 \mu \mathrm{M}$ and chl a concentration ranged from 81.5 to $211.8 \mu \mathrm{g} \mathrm{l}^{-1}$. In 2 of 3 diel cycles the nighttime urea decomposition rate in whole waters was higher than the daytime decomposition rate; in 1 diel experiment the nighttime decomposition rate was $56.4 \%$ of the daytime rate, indicating that the variation of urea decomposition rate was not associated with natural light/dark cycles. Despite the very high ammonium concentrations, substantial urea decomposition rates $\left(5.5\right.$ to $\left.80.8 \mathrm{nM} \mathrm{h}^{-1}\right)$ were observed, particularly in June and September. Such high decomposition rates were due to high chl a-specific activity rather than due to large phytoplankton biomass and low activity. When urea concentration was high (ca $>2 \mu \mathrm{M}$ ), the urea decomposition rate showed a linear increase with increasing urea concentration even in the presence of high ammonium concentrations (range of 123.6 to $403.6 \mu \mathrm{M}$ ), suggesting that elevated urea concentration mitigates the repressive effect of ammonium on urea decomposition. The urea decomposition rate in GF/C filtrates (mainly bacterial-size fractions) ranged from negligible to $39.3 \mathrm{nM} \mathrm{h}^{-1}$, representing an average of $47.1 \%$ of the activity in whole pond waters. This study suggests that urea decomposition activity in an ammonium enriched freshwater pond is significantly elevated and controlled by the urea concentration, and that bacteria might contribute substantially to urea decomposition rate in a hypertrophic freshwater pond.
\end{abstract}

KEY WORDS: Urea decomposition · Hypertrophic freshwater pond · Urea · Ammonium - Bacteria - Diel cycle

\section{INTRODUCTION}

In most aquatic environments, urea is primarily decomposed by phytoplankton and is one of the most important nitrogen sources for phytoplankton growth (Remsen et al. 1972, Turley 1985, Mitamura \& Saijo 1986, Shim et al. 1994, Cho \& Azam 1995, Tamminen \& Irmisch 1996). The decomposition of urea by phytoplankton is known to be controlled by light (Webb \& Hass 1976), ammonium concentration (Horrigan \& McCarthy 1982, Park et al. 1993, Tamminen \& Irmisch, 1996) and water temperature (Mitamura 1986b). Webb \& Hass (1976) reported the diel periodicity of urea decomposition in the York River and observed a zero

-Addressee for correspondence. E-mail: bccho@plaza.snu.ac.kr rate of urea decomposition during the nighttime. The presence of ammonium has often been reported to inhibit urea decomposition in phytoplankton in both seawater and batch cultures of marine diatoms (Horrigan \& McCarthy 1982, Tamminen \& Irmisch 1996). Using ${ }^{15} \mathrm{~N}$-labelled urea, Mitamura (1986b) found that urea uptake was suppressed 15 to $30 \%$ by ammonium concentration greater than $1 \mu \mathrm{M}$ in Lake Biwa. Tight coupling between ${ }^{14} \mathrm{C}$-urea decomposition rates and ${ }^{15} \mathrm{~N}$-urea uptake rates in Lake Biwa (Mitamura \& Saijo 1986) suggests that urea decomposition might occur above $1 \mu \mathrm{M}$ ammonium concentration. The close examination of data reported by Mitamura \& Saijo (1986) in Lake Biwa showed that when urea concentrations ranged from 0.5 to $2 \mu \mathrm{M}$, urea decomposition rates were significant (range of 5 to $17 \mathrm{nM} \mathrm{h}^{-1}$ ) even in the 
presence of ammonium concentrations between 2 and $13 \mu \mathrm{M}$, whereas when urea concentrations were less than $0.5 \mu \mathrm{M}$, urea decomposition rates were low (usually $<1 \mathrm{nM} \mathrm{h}^{-1}$ ) at ammonium concentrations greater than $2 \mu \mathrm{M}$. Thus, it seems that the effect of ammonium concentration on urea decomposition depends on urea concentration as well.

Until now, there has been little information about urea decomposition in ammonium enriched $(>100 \mu \mathrm{M})$, hypertrophic waters. Although a few measurements of urea decomposition rates in ammonium enriched, polluted waters showed low urease activity (Mitamura et al. 1994), the effect of elevated concentrations of ammonium on urea decomposition activity remained relatively unknown. In this study, we address the following questions: Can we detect substantial activity of urea decomposition in the presence of very high ammonium concentrations ( $>100 \mu \mathrm{M})$ ? What environmental parameters control urea decomposition? We measured urea decomposition activities in the sizefractionated samples during 3 diel cycles in an ammonium enriched freshwater pond. Here, we report that urea decomposition activities were mainly controlled by urea concentrations in the presence of high ammonium concentrations, and bacteria might contribute substantially to urea decomposition in a hypertrophic freshwater pond. Significant rates of urea decomposition were observed in the dark during the diel cycles.

\section{MATERIALS AND METHODS}

Study area and sample collection. Water samples were taken from an artificial freshwater pond within Seoul National University, located in Seoul, Republic of Korea. The freshwater pond has a mean depth of $1.5 \mathrm{~m}$ and its surface area covers about $3200 \mathrm{~m}^{2}$. The surface water samples were collected with an acidwashed Niskin bottle at 5 to $7 \mathrm{~h}$ intervals for $40 \mathrm{~h}$ at the center of the pond during 3 diel cycles: June 27 to 28, September 6 to 7,1992 and February 14 to 15, 1993

Urea decomposition. For determination of urea decomposition rates, we followed basically the method of Remsen et al. (1972). Briefly, $50 \mathrm{ml}$ of pond water was inoculated with 0.2 um filter-sterilized ${ }^{14} \mathrm{C}$-urea (specific activity $55.3 \mathrm{mCi} \mathrm{mmol}^{-1}$, Amersham) to attain the final concentration of added urea of $46.5 \mathrm{nM}$. Samples were incubated under natural light conditions for $4 \mathrm{~h}$ at in situ temperature. To correct for abiotic decomposition of urea, formalin-added (final conc. of $2 \%$ ) controls were run with each set of samples. After incubation with ${ }^{14} \mathrm{C}$-urea, $1 \mathrm{ml}$ of $2 \mathrm{~N} \mathrm{H}_{2} \mathrm{SO}_{4}$ was added and the liberated ${ }^{14} \mathrm{CO}_{2}$ was collected and radioassayed. All measurements were done in triplicates. The radioactivity was measured by a liquid scintillation counter
(Packard Tri-Carb, Model 2550) using the external standard ratio method. To determine whether phytoplankton or bacteria were important in urea decomposition, whole water and size-fractionated water samples through Whatman GF/C filters with a nominal pore size of $1.2 \mu \mathrm{m}$ (vacuum $<100 \mathrm{~mm} \mathrm{Hg}$ ) were incubated with addition of ${ }^{14} \mathrm{C}$-urea as above. All samples of $\mathrm{GF} / \mathrm{C}$ filtrates were incubated in the dark. Urea decomposition rates $(V)$ were calculated as: $V=\left(V_{\mathrm{L}} \times S\right) /\left(A_{\mathrm{d}} \times t\right)$, where $V_{\mathrm{L}}$ is the activity of the liberated ${ }^{14} \mathrm{CO}_{2 i} S_{\text {, in situ }}$ concentration of urea; $A_{d}$ the radioactivity of added urea; and $t(h)$, duration of incubation (Turley 1985). The fraction of ${ }^{14} \mathrm{C}$-urea carbon incorporated into the particulate matter was measured through filtering onto $0.22 \mu \mathrm{m}$ Millipore filters after the capture of the liberated ${ }^{14} \mathrm{CO}_{2}$. During this study, the fractions of ${ }^{14} \mathrm{C}$-urea carbon incorporated into the particulate matter were on average $8.0 \pm 7.8 \%(n=17)$ and $2.8 \pm 5.1 \%(n=17)$ of urea decomposition in whole waters and GF/C filtrates, respectively. To retain comparability with previous studies (Tamminen \& Irmish 1996), all results in this study referred to the liberated ${ }^{14} \mathrm{CO}_{2}$ unless otherwise stated. Turnover time of urea was calculated as $\left(A_{d} \times\right.$ t) $/ V_{\mathrm{L}}$. Chl a-specific urea decomposition rates were calculated by dividing the whole water minus GF/C filtrate decomposition rates by chl a concentrations.

Other analyses. Water temperature was measured by mercury thermometer. Urea concentrations were measured by the diacetyl monoxime thiosemicarbazide method described by Price \& Harrison (1987). Ammonium concentrations were measured according to Grasshoff et al. (1983). For the measurement of chl a concentrations, samples were filtered onto Whatman GF/F filters (nominal pore size of $0.7 \mu \mathrm{m}$ ) and measured by the spectrophotometric method (Parsons et al. 1984). At our study site, chl a concentrations measured on $\mathrm{GF} / \mathrm{C}$ and $\mathrm{GF} / \mathrm{F}$ filters showed statistically no significant difference (not shown).

\section{RESULTS}

\section{Diel variations of environmental parameters}

Water temperatiures rancied from 3.8 to $27.0^{\circ} \mathrm{C}$ during 3 diel cycles (Fig. 1a). The daily variation of water temperature was $3.5^{\circ} \mathrm{C}$ (range of 20.5 to $24.0^{\circ} \mathrm{C}$ ) in June, but was smaller in September $\left(3^{\circ} \mathrm{C}\right.$, range of 24.0 to $27.0^{\circ} \mathrm{C}$ ) and February $\left(1^{\circ} \mathrm{C}\right.$, range of 3.8 to $4.8^{\circ} \mathrm{C}$ ). Water temperature was always high during the daytime and low during the nighttime (Fig. 1a). Urea concentration ranged from $1.3 \mu \mathrm{M}$ in February to $9.1 \mu \mathrm{M}$ in June during the study period (Fig. 1b). The urea concentration tended to be higher during the nighttime than during the daytime in June, but in Septem- 
ber and February showed no marked diel variations. Extremely high ammonium concentrations $(>100 \mu \mathrm{M})$ were found throughout the study period (Fig 1c). Ammonium concentrations ranged from $123.6 \mu \mathrm{M}$ in September to 403.6 $\mathrm{\mu M}$ in June. Ammonium concentrations were higher during the nighttime than the daytime in June, but similar between daytime and nighttime in September and February. Chl a concentrations were very high (usually $>100 \mu \mathrm{gl}^{-1}$ ), ranging from $81.5 \mathrm{\mu g} \mathrm{l}^{-1}$ (in September) to $211.8 \mu \mathrm{g} \mathrm{l}^{-1}$ (in September ${ }_{i}$ Fig. 1d). During 3 diel cycles, chl a did not show marked diel patterns.

\section{Diel variations of urea decomposition}

The urea decomposition rate in whole waters showed large variations ( 2 orders of magnitude) during the study period with a range of 0.6 to $80.8 \mathrm{nM} \mathrm{h}^{-1}$ (Fig. $2 \mathrm{a}-\mathrm{c}$ ). In June, the peak urea decomposition rate in whole waters occurred during the night, coinciding with the highest measured level of urea (Fig. 1b). The urea decomposition rate in GF/C filtrates decreased in the early part of the dark period when urea concentration was at the minimum, but resumed concomitantly with increases in urea concentration. The diel variation of urea decomposition rates was somewhat different between whole waters and GF/C filtrates (Fig. 2a). In September, the urea decomposition rate in whole waters was lower during the dark period (Fig 2b) and resumed in the next light period. However, during the nighttime, the urea decomposition rate in whole waters represented $56.4 \%$ of those during the daytime $\left(11.7 \pm 2.2 \mathrm{nM} \mathrm{h}^{-1}, \mathrm{n}=4\right)$. GF/C filtrates showed a similar trend to whole waters, but a minimal urea decomposition rate was found after the dark period. In February, 2 peaks of urea decomposition rates were found in both the dark and light period, although urea concentration did not change substantially during the diel cycle (Fig. 1b). The urea decomposition rate in $\mathrm{GF} / \mathrm{C}$ filtrates did not show a diel variation. Our results indicated that diel variations of urea decomposition in both whole waters and GF/C filtrates were not affected by the natural light/dark cycles.

Urea decomposition rates in $\mathrm{GF} / \mathrm{C}$ filtrates (mainly bacterial-size fractions) ranged from negligible to $39.3 \mathrm{nM} \mathrm{h}^{-1}$ during the study period, which represented on average $47.1 \pm 25.0 \%$ (range of 0 to $90 \%, n=$ 17) of the urea decomposition rate in whole waters (Table 1). In June, the urea decomposition rate in GF/C filtrates ranged from negligible to $39.3 \mathrm{nM} \mathrm{h}^{-1}$ (on average $56.8 \%$ of whole waters). In September and February, the rates ranged from 1.5 to $9.1 \mathrm{nM} \mathrm{h}^{-1}$ (on average $50.3 \%$ of whole waters) and 0.2 to $0.4 \mathrm{nM} \mathrm{h}^{-1}$ (on average $31.6 \%$ of whole waters), respectively.
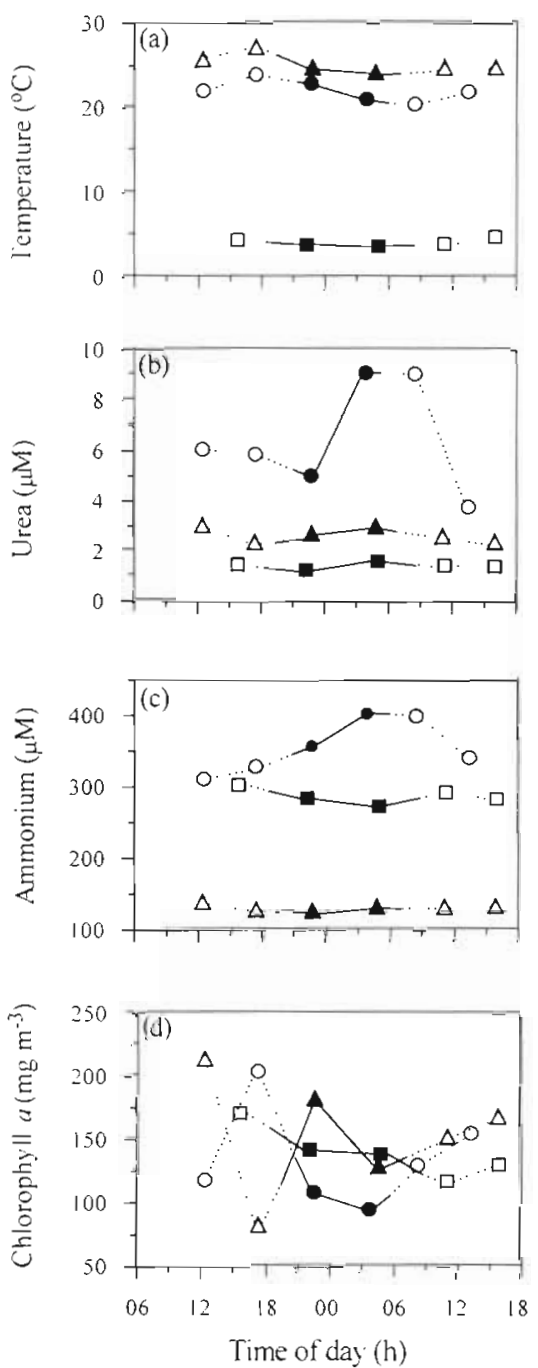

Fig. 1. (a) Temperature, (b) urea concentrations, (c) ammonium concentrations, and (d) chlorophyll a during 3 diel cycles. Data were collected during June 27 and 28, 1992 (0. -) September 6 and 7, $1992(\Delta, \mathbf{\Delta})$, and February 14 and 15 , 1993 (ㅁ, - ), respectively. Open symbols and dotted lines represent the light period; closed symbols and solid lines the dark period

Chl a-specific urea decomposition rates showed the

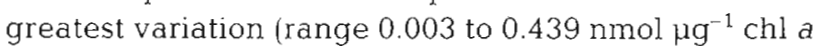
$\mathrm{h}^{-1}$ ) during the study period (Table 1): 0.025 to

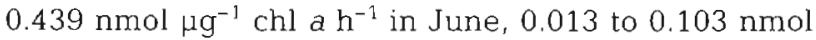
$\mu^{-1} \mathrm{chl} \mathrm{a} \mathrm{h}^{-1}$ in September, and 0.003 to $0.009 \mathrm{nmol}$ $\mu^{-1}$ chl a $\mathrm{h}^{-1}$ in February. The chl a-specific urea decomposition rates also demonstrated similar diel patterns as the whole urea decomposition rates (Fig. 2d-f): in June, the peak chl a-specific urea decomposition rate was found in the nighttime. In September, the chl a-specific urea decomposition rate showed a weak diel pattern with maximal rates during the daytime and minimal rates during the nighttime. In February, 2 peaks of chl a-specific urea decomposition rates 


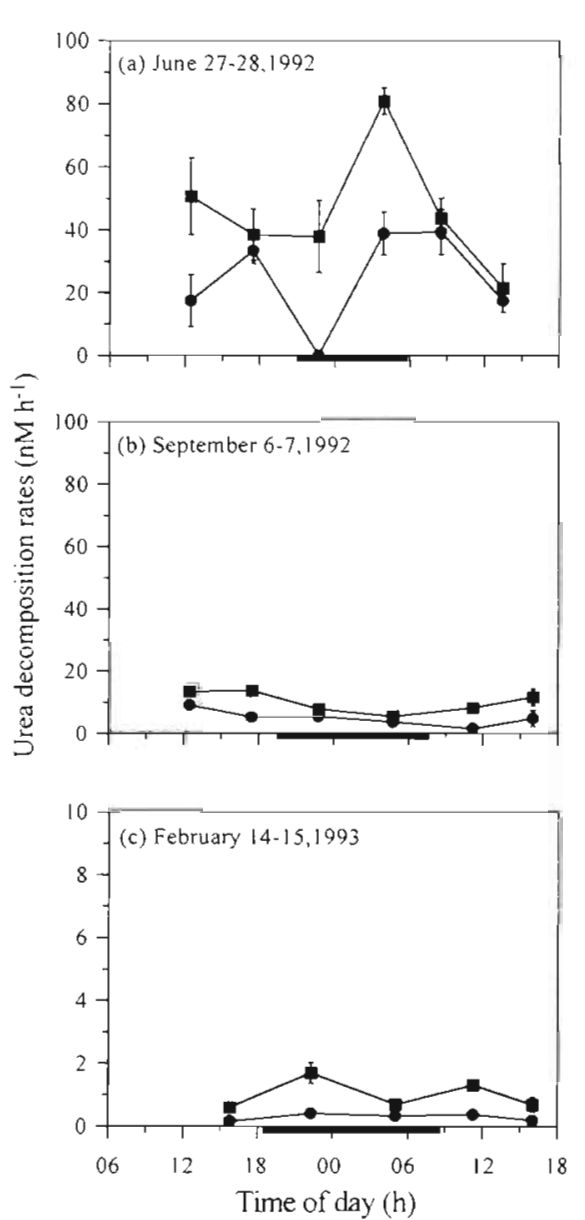

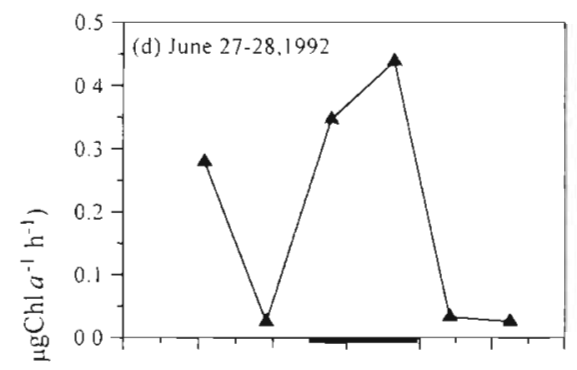

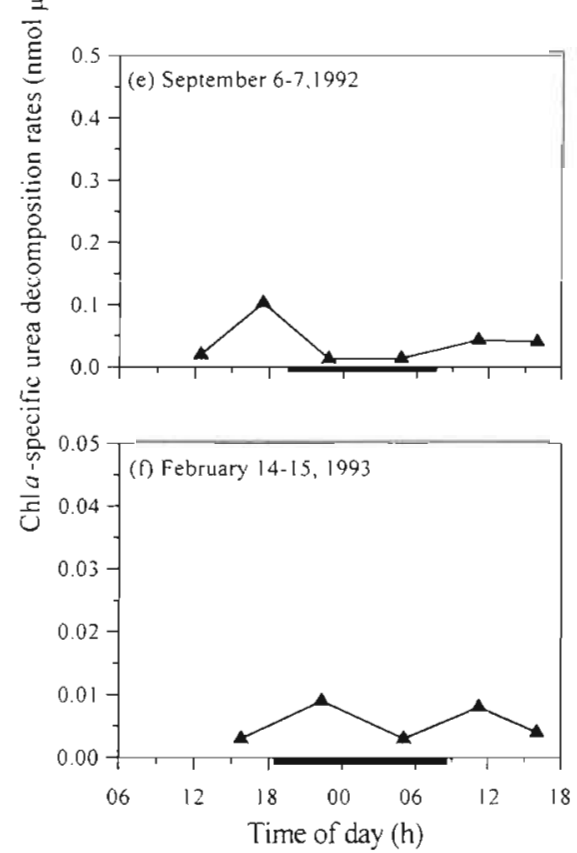

Fig. 2. Diel cycles of $(\mathrm{a}-\mathrm{c})$ urea decomposition rates in whole waters $(\boldsymbol{\square})$ and $\mathrm{GF} / \mathrm{C}$ filtrates $(\bullet)$ and $(\mathrm{d}-\mathrm{f} ; \boldsymbol{\Delta}) \mathrm{chl} a-$ specific urea decomposition rates during 3 diel cycles. Vertical bars represent 1. SD. Dark bars represent dark period during each diel cycle were found in both the dark and the light period, which is similar to the pattern of whole urea decomposition rates, indicating that chl a-specific urea decomposition rates were also not closely related to the photoperiod.

\section{Urea turnover}

Turnover times of urea (Table 1) were relatively short in June $(6.3 \pm 1.4 \mathrm{~d}, \mathrm{n}=6)$ and September $(12.1 \pm$ $5.0 \mathrm{~d}, \mathrm{n}=6$ ) despite the very high ammonium concentrations. In February, however, urea was turned over very slowly ( $>1 \mathrm{mo})$, probably due to low water temperature (Fig. 1a).

\section{Correlation between urea decomposition activity and urea concentration}

The plots of urea concentration versus decomposition rate for all data are shown in Fig. 3. The urea decomposition rate in whole waters was significantly positively correlated to urea concentration $\left(r^{2}=0.88\right.$, $p<0.001$; Fig. 3a). The correlation between the urea decomposition rate and urea concentration in GF/C filtrates was also significant $\left(r^{2}=0.82, p<0.001\right.$; Fig. $\left.3 b\right)$. The $x$ intercepts of linear regression equations between urea concentrations and decomposition rates were similar in both whole waters (ca $1.3 \mu \mathrm{M}$ ) and $\mathrm{GF} / \mathrm{C}$ filtrates (ca $1.5 \mu \mathrm{M}$ ), whereas the slope was greater (ca $70 \%$ ) in whole waters than in GF/C filtrates, indicating that phytoplankton probably respond more rapidly to high urea concentration than do bacteria. The urea decomposition rate in whole waters was not significantly correlated to chl a concentrations $\left(\mathrm{r}^{2}=\right.$ $0.08, p=0.265, n=17$, not shown).

\section{DISCUSSION}

\section{Urea decomposition in high ammonium enriched freshwater pond}

A noteworthy result from this study was that substantial rates of urea decomposition (0.6 to $80.8 \mathrm{nM} \mathrm{h}^{-1}$ ) were observed even in an ammonium enriched $(>100 \mu \mathrm{M})$, hypertrophic freshwater environment (chl a $>100 \mu \mathrm{g} \mathrm{l}^{-1}$ ). Our values of urea decomposition 
Table 1. Urea decomposition (UD) rates in whole waters and GF/C filtrates, ratio of UD between GF/C filtrate and whole water, chlorophyll a (chl a) concentrations, chl a-specific UD rates, turnover times (TO) during 3 diel cycles. nd: not detected

\begin{tabular}{|c|c|c|c|c|c|c|}
\hline $\begin{array}{l}\text { Sampling } \\
\text { time (h) }\end{array}$ & Size fraction & $\begin{array}{l}\text { UD rate } \\
\left(\mathrm{nM} \mathrm{h}^{-1}\right)\end{array}$ & $\frac{\text { UD in GF/C filtrate }}{\text { UD in whole water }}(\%)$ & $\begin{array}{c}\text { Chla } \\
\left(\mu g l^{-1}\right)\end{array}$ & $\begin{array}{l}\text { Chl a-specific UD rate } \\
\left(\mathrm{nmol} \mu \mathrm{g}^{-1} \mathrm{chl} a \mathrm{~h}^{-1}\right)\end{array}$ & $\begin{array}{l}\text { TO } \\
\text { (d) }\end{array}$ \\
\hline \multicolumn{7}{|c|}{ 27-28 June 1992} \\
\hline $10: 10$ & $\begin{array}{l}\text { Whole } \\
\text { GF/C filtrate }\end{array}$ & $\begin{array}{l}50.63 \\
17.44\end{array}$ & 34.5 & 118.6 & 0.280 & 5.0 \\
\hline $14: 45$ & $\begin{array}{l}\text { Whole } \\
\text { GF/C filtrate }\end{array}$ & $\begin{array}{l}38.46 \\
33.37\end{array}$ & 86.8 & 204.0 & 0.025 & 6.3 \\
\hline $20: 10$ & $\begin{array}{l}\text { Whole } \\
\text { GF/C filtrate }\end{array}$ & $\begin{array}{l}37.86 \\
\text { nd }\end{array}$ & 0.0 & 109.2 & 0.347 & 5.5 \\
\hline 01:15 & $\begin{array}{l}\text { Whole } \\
\text { GF/C filtrate }\end{array}$ & $\begin{array}{l}80.80 \\
38.82\end{array}$ & 48.1 & 95.6 & 0.439 & 4.7 \\
\hline $06: 30$ & $\begin{array}{l}\text { Whole } \\
\text { GF/C filtrate }\end{array}$ & $\begin{array}{l}43.68 \\
39.32\end{array}$ & 90.0 & 130.6 & 0.033 & 8.7 \\
\hline $10: 30$ & $\begin{array}{l}\text { Whole } \\
\text { GF/C filtrate }\end{array}$ & $\begin{array}{l}21.48 \\
17.46\end{array}$ & 81.3 & 155.7 & 0.026 & 7.3 \\
\hline \multicolumn{7}{|c|}{ 6-7 September 1992} \\
\hline $10: 10$ & $\begin{array}{l}\text { Whole } \\
\text { GF/C filtrate }\end{array}$ & $\begin{array}{r}13.42 \\
9.10\end{array}$ & 67.8 & 211.8 & 0.020 & 9.1 \\
\hline $14: 45$ & $\begin{array}{l}\text { Whole } \\
\text { GF/C filtrate }\end{array}$ & $\begin{array}{r}13.67 \\
5.26\end{array}$ & 38.5 & 81.5 & 0.103 & 6.9 \\
\hline $20: 10$ & $\begin{array}{l}\text { Whole } \\
\text { GF/C filtrate }\end{array}$ & $\begin{array}{l}7.79 \\
5.39\end{array}$ & 69.2 & 181.0 & 0.013 & 13.9 \\
\hline $01: 30$ & $\begin{array}{l}\text { Whole } \\
\text { GF/C filtrate }\end{array}$ & $\begin{array}{l}5.47 \\
3.62\end{array}$ & 66.2 & 127.7 & 0.014 & 21.9 \\
\hline 08:00 & $\begin{array}{l}\text { Whole } \\
\text { GF/C filtrate }\end{array}$ & $\begin{array}{l}8.15 \\
1.54\end{array}$ & 18.9 & 150.4 & 0.044 & 12.7 \\
\hline $14: 20$ & $\begin{array}{l}\text { Whole } \\
\text { GF/C filtrate }\end{array}$ & $\begin{array}{r}11.66 \\
4.83\end{array}$ & 41.4 & 167.3 & 0.041 & 8.1 \\
\hline \multicolumn{7}{|c|}{$14-15$ February 1993} \\
\hline $12: 30$ & $\begin{array}{l}\text { Whole } \\
\text { GF/C filtrate }\end{array}$ & $\begin{array}{l}0.60 \\
0.17\end{array}$ & 28.1 & 171.6 & 0.003 & 103.8 \\
\hline $19: 00$ & $\begin{array}{l}\text { Whole } \\
\text { GF/C filtrate }\end{array}$ & $\begin{array}{l}1.70 \\
0.42\end{array}$ & 24.8 & 142.4 & 0.009 & 30.7 \\
\hline $01: 30$ & $\begin{array}{l}\text { Whole } \\
\text { GF/C filtrate }\end{array}$ & $\begin{array}{l}0.70 \\
0.33\end{array}$ & 47.0 & 139.7 & 0.003 & 96.5 \\
\hline $08: 30$ & $\begin{array}{l}\text { Whole } \\
\text { GF/C filtrate }\end{array}$ & $\begin{array}{l}1.31 \\
0.38\end{array}$ & 29.1 & 117.9 & 0.008 & 46.2 \\
\hline $14: 00$ & $\begin{array}{l}\text { Whole } \\
\text { GF/C filtrate }\end{array}$ & $\begin{array}{l}0.69 \\
0.20\end{array}$ & 28.8 & 130.2 & 0.004 & 84.4 \\
\hline
\end{tabular}

rates in greatly ammonium enriched freshwater are even comparable to or an order of magnitude higher than previously attained values from other freshwater environments in which ammonium concentrations were lower than $14 \mu \mathrm{M}$ (Table 2); Mitamura \& Saijo (1976, 1986), Mitamura \& Matsumoto (1981) and Mitamura (1986a) reported urea decomposition rates of 0.6 to $17.6 \mathrm{nM} \mathrm{h}^{-1}$ in surface waters of Lake Biwa. In the Rio Doce Valley Lake System and surface waters of reservoirs associated with the Han River, Mitamura et al. $(1989,1994,1995 \mathrm{a}$, b) have reported decomposition rates of 0.04 to $4.96 \mathrm{nM} \mathrm{h}^{-1}$. Freshwater environments studied by Mitamura and his colleagues were all oligoto eutrophic, where ammonium concentrations were usually less than $14 \mu \mathrm{M}$ and chl a concentrations ranged from 0.5 to $50.6 \mu \mathrm{g} \mathrm{l}^{-1}$. In contrast, ammonium concentrations in our study area measured up to 100 fold greater. Urea decomposition activity had previously been reported to be inhibited by ammonium concentration greater than $1 \mu \mathrm{M}$ in both seawater and batch cultures of marine diatoms (Horrigan \& McCarthy 1982, Tamminen \& Irmisch 1996). Based on the works of Mitamura (1986b) and Mitamura \& Saijo (1986) in Lake Biwa, urea decomposition in freshwaters seemed to be inhibited by ammonium concentrations greater than $1 \mu \mathrm{M}$. Despite the very high ammonium concentrations in our samples, urea decomposition rates appeared substantially elevated, particularly in June and September. To determine whether the high urea decomposition rates were due to large phytoplankton biomass and low activity in our study site or due to high chl a-specific activity, chl a- 

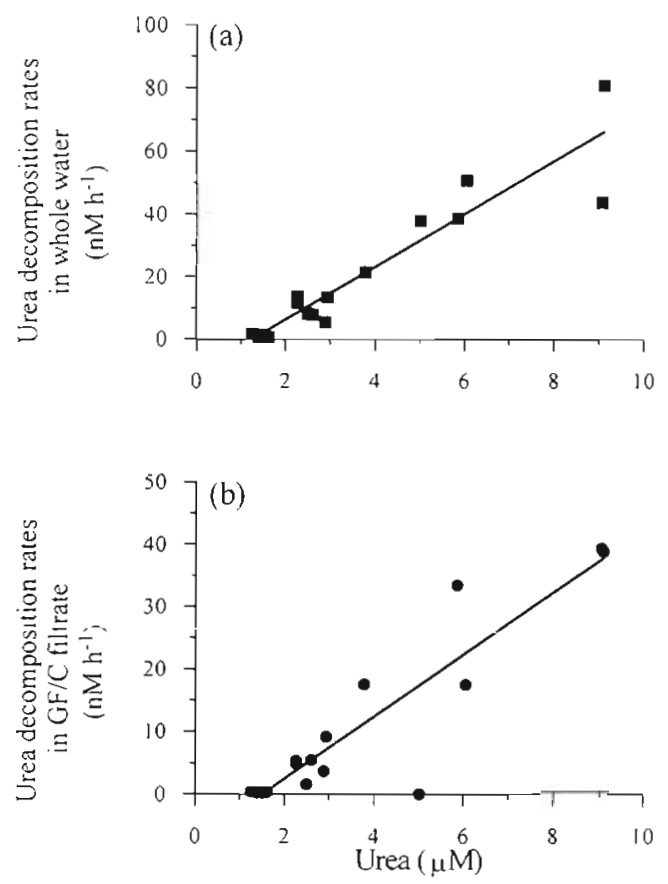

Fig. 3. Plots of urea decomposition rates (whole waters and $\mathrm{GF} / \mathrm{C}$ filtrates) versus urea concentrations for all data during the study period when ammonium concentrations ranged from 123.6 to $403.6 \mu \mathrm{M}$. In (a) whole water and (b) GF/C filtrate, the linear regression equations are $y=8.41 x-10.56$ $\left(r^{2}=0.88, p<0.001\right)$ and $y=4.96 x-7.51\left(r^{2}=0.82, p<0.001\right)$, respectively, where $x$ and $y$ denote urea concentrations and urea decomposition rates, respectively

specific urea decomposition rates were compared with other studies (Table 2). Chl a-specific urea decomposition rates $\left(0.013\right.$ to $\left.0.439 \mathrm{nmol} \mu \mathrm{g}^{-1} \mathrm{chl} a \mathrm{~h}^{-1}\right)$ in June and September are within the ranges $(0.008$ to 3.023 $\mathrm{nmol} \mathrm{gg}^{-1} \mathrm{chl} \mathrm{a} \mathrm{h}^{-1}$ ) reported from the other freshwater environments where ammonium concentrations were lower than $14 \mu \mathrm{M}$ (Table 2). There are rare measurements in the hypertrophic environments to which we compare our urea decomposition rates and chl a-specific urea decomposition rates. In the polluted waters of the North Han River with ammonium concentrations of 122 to $211 \mu \mathrm{M}$, Mitamura et al. (1994) obtained similar chl a-specific urea decomposition rates (but much lower urea decomposition rates with the ranges of 1.0 to $2.8 \mathrm{nM} \mathrm{h}^{-1}$ due to low chl a) to our values (Table 2). Thus, urea decomposition activities in June and September were not suppressed by the very high ammonium concentrations. Our results are intriguing in view of the fact that $\mu \mathrm{M}$ levels of ammonium are known to inhibit urea decomposition (Horrigan \& McCarthy 1982. Mitamura 1986b, Tamminen \& Irmisch 1996). The substantial activity of urea decomposition was reflected by relatively rapid turnover times of urea (on average 9.2 d) during June and September. When urea concentrations were above $2 \mu \mathrm{M}$, the urea decomposition rate showed a linear increase with increasing urea concentration (Fig. 3) even in the presence of high ammonium concentration (>100 $\mu \mathrm{M}$ ), suggesting that elevated urea concentration mitigates the repressive effect of ammonium on urea decomposition even when ammonium concentrations are also high. In fact, at the same study site, addition of $500 \mu \mathrm{M}$ ammonium only reduced the in situ urea decomposition activity to half, indicating that phytoplankton ureases are still active at such high ammonium concentrations (Park et al. 1993).

A significant correlation between the urea decomposition rate in whole waters (and GF/C filtrates) and urea concentration (Fig. 3) suggests that urea concentration is one of the main controlling factors of urea decomposition activity in our study sitc. Urea decomposition activity is also known to be controlled by light (Webb \& Hass 1976) and water temperature (Mitamura 1986b). Webb \& Hass (1976) observed a diel periodicity of urea decomposition with maximal rates during midday and zero rates at night in the York River, suggesting that urea decomposition was light dependent. But, Mitamura \& Saijo (1986) reported in eutrophic Lake Biwa that the variation of the urea decomposition rate in whole waters was not associated with the light/dark cycles, similar to our results. Furthermore, we could not find any significant relationship between the urea decomposition rate and water temperature during each diel cycle and for all pooled data (not shown).

\section{Bacterial urea decomposition activity}

It is well known that urea is decomposed in surface waters primarily by phytoplankton rather than bacteria in most freshwater and marine environments (Remsen et al. 1972, Turley 1985, Mitamura \& Saijo 1986, Shim et al. 1994, Cho \& Azam 1995, Tamminen \& Irmisch $1996)$. Yet, GF/C filtrates in this study had on average $47 \%$ of whole water's urea decomposition activity (Table 1). We regarded urea decomposition in the GF/C filtrate as bacterial activity for the following reasons. Data obtained from the same seasons during the following years at our study site indicated that GF/C filtrates comprised from 0 to $6 \%$ of total $\mathrm{chl} a_{\text {, but from }}$ 62 to $83 \%$ of total bacteria $\left(6.8\right.$ to $\left.34.9 \times 10^{9} \mathrm{l}^{-1}\right)$ counted by epifluorescence microscopy of acridine orange stained samples (not shown). Using the simple equations incorporating the proportions of bacteria and chl $a$ in the GF/C filtrate and total urea decomposition activity in whole water, we estimated urea decomposition activity in bacteria and phytoplankton assuming the same chl a-specific urea decomposition activity in phytoplankton present in GF/C filtrate as that in whole 


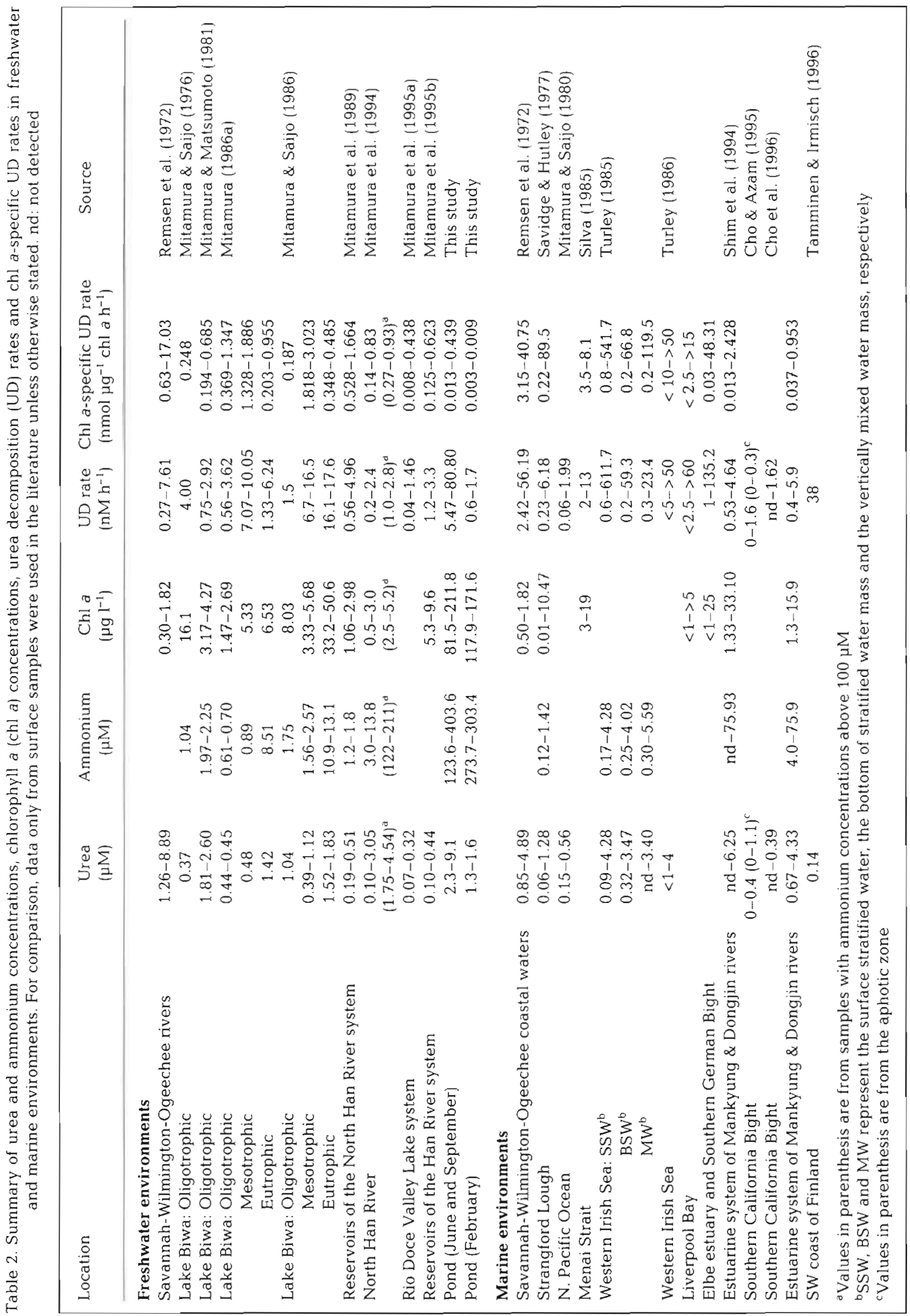


water. We found that the estimated rates of urea decomposition in bacteria were similar to those measured in GF/C filtrates (i.e. bacterial fraction), and that the estimated rates in phytoplankton were similar to those calculated in phytoplankton fraction (i.e. whole water minus GF/C filtrate). Even if chl a-specific urea decomposition rates in the GF/C filtrates were a few fold higher than those of phytoplankton fraction (this is often observed in literature), our general conclusion would not be much affected. Therefore, bacteria seemed to contribute to urea decomposition in GF/C filtrates which were incubated in the dark. This is an interesting contrast to euphotic marine systems where bacteria only make a minor contribution to urea decomposition, but not dissimilar to aphotic marine waters (Cho \& Azam 1995). Until now, bacterial urea decomposition activity has been suggested to be very low although urea-decomposing bacteria do commonly exist in freshwaters (Satoh \& Hanya 1976, Satoh 1980). Satoh \& Hanya (1976) have reported that bacteria in eutrophic pond water, separated by filtration through Whatman GF/C filters, did not decompose urea at a concentration of about $5 \mu \mathrm{M}$ for $18 \mathrm{~d}$. Satoh (1980) has suggested that urea concentrations in natural waters (usually less than $1 \mu \mathrm{M}$ ) were below the critical level for bacterial utilization. The presence of active urea decomposition in the night and the differing behaviors of urea decomposition between whole waters and $\mathrm{GF} / \mathrm{C}$ filtrates support the idea that substantial activity of bacterial urea decomposition is possible in our samples. Furthermore, poor correlation between urea decomposition rates in whole waters and chl a concentration is consistent with the notion that bacteria could be responsible for urea decomposition in our samples.

In summary, urea decomposition activity in an ammonium enriched freshwater pond was substantially elevated and apparently controlled by urea concentrations. Our results also suggest that bacteria are important in urea decomposition in a hypertrophic environment.

Acknowledgements. We thank Dr Raphael M. Kudela (Monterey Bay Aquarium Research Institute) for his valuable comments. We also appreciate the constructive suggestions of our 3 anunynums leviewers. The preseni siudy was suppos ied in part) by the Basic Science Research Institute Program, Ministry of Education, 1996. Project No. BSRI-96-5409.

\section{LITERATURE CITED}

Cho BC, Azam F (1995) Urea decomposition by bacteria in the Southern California Bight and its implications for the mesopelagic nitrogen cycle. Mar Ecol Prog Ser 122:21-26

Cho BC, Park MG, Shim JH, Azam F (1996) Significance of bacteria in urea dynamics in coastal surface waters. Mar Ecol Prog Ser 142:19-26
Grasshoff K, Ehrhardt M, Kremling K (1983) Methods of seawater analysis. Verlag Chemie, Weinheim

Horrigan SG, McCarthy JJ (1982) Phytoplankton uptake of ammonium and urea during growth on oxidized forms of nitrogen. J Plankton Res 4:379-389

Mitamura $O$ (1986a) Urea metabolism and its significance in the nitrogen cycle in the euphotic layer of Lake Biwa. II Half-saturation constant for nitrogen assimilation by fractionated phytoplankton in different trophic areas. Arch Hydrobiol 107:167-182

Mitamura $O$ (1986b) Urea metabolism and its significance in the nitrogen cycle in the euphotic layer of Lake Biwa. III Influence of the environmental parameters on the response of nitrogen assimilation. Arch Hydrobiol 107:281-299

Mitamura O, Cho KS, Hong SU (1994) Urea decomposition associated with the activity of microorganisms in surface waters of the North Han River, Korea. Arch Hydrobiol 131 $231-242$

Mitamura O, Cho KS, Hong SU, Lee HK (1989) Urea decomposition and its turnover time in euphotic layer of reservoirs in the north Han River system. Kor J Limnol 22:227-238

Mitamura O, Matsumoto K (1981) Uptake rate of urea nitrogen and decomposition rate of urea carbon at the surface microlayer in Lake Biwa. Verh Int Verein Limnol 21:556-564

Mitamura O, Saijo Y (1976) Decomposition of urea in Lake Biwa. Physiol Ecol Japan 17:601-605

Mitamura O, Saijo Y (1980) In situ measurement of the urea decomposition rate and its turnover rate in the Pacific Ocean. Mar Biol 58:147-152

Mitamura O, Saijo Y (1986) Urea metabolism and its significance in the nitrogen cycle in the euphotic layer of Lake Biwa. I. In situ measurement of nitrogen assimilation and urea decomposition. Arch Hydrobiol 107:23-51

Mitamura O, Saijo Y, Hino K (1995a) Cycling of urea associated with photosynthetic activity of phytoplankton in the euphotic zone of tropical lakes, Brazil. Jpn J Limnol 56: 95-105

Mitamura O, Tachibana J, Kamitani H, Kim BC, Cho KS (1995b) Comparative investigation of the urea degradation in reservoirs of the Han River system. Kor J Limnol 28: $115-125$

Park MG, Shim JH, Cho BC (1993) Adaptations of estuarine and freshwater phytoplankton to urea decomposition. J Oceanol Soc Korea 28:323-331

Parsons TR, Maita Y, Lalli CM (1984) A manual of chemical and biological methods for seawater analysis. Pergamon, New York

Price NM, Harrison PJ (1987) A comparison of methods for the measurement of dissolved urea concentrations in seawater. Mar Biol 92:307-319

Remsen CC, Carpenter EJ, Schroeder BW (1972) Competition for urea among estuarine microorganisms. Ecology 53: $921-926$

Satoh Y (1980) Distribution of urea-decomposing bacteria in waies of Lake Suwa. Hyciuvioiugid $71: 233-237$

Satoh Y, Hanya $T$ (1976) Decomposition of urea by the larger particulate fraction and free bacteria fraction in a pond water. Int Rev Ges Hydrobiol 61:799-806

Savidge G. Hutley HT (1977) Rates of remineralization and assimilation of urea by fractionated plankton populations in coastal waters. J Exp Mar Biol Ecol 28:1-16

Shim JH, Cho BC, Park MG (1994) Distributions of urea and urea decomposition rates in an estuarine system of Mankyung and Dongjin Rivers, Korea. J Oceanol Soc Korea 29:402-413

Silva EM (1985) Microbial decomposition of urea in the Menai Straits. Hydrobiologia 126:245-251 
Tamminen T, Irmisch A (1996) Urea uptake kinetics of a midsummer planktonic community on the SW coast of Finland. Mar Ecol Prog Ser 130:201-211

Turley CM (1985) Biological studies in the vicinity of a shallow-sea tidal mixing front. IV. Seasonal and spatial distribution of urea and its uptake by phytoplankton. Phil Trans $\mathrm{R}$ Soc Lond B 310:471-500

Responsible Subject Editor: Farooq Azam, La Jolla, California, USA
Turley CM (1986) Urea uptake by phytoplankton at different fronts and associated stratified and mixed waters on the European shelf. Brit Phycol J 21:225-238

Webb KL, Hass LW (1976) The significance of urea for phytoplankton nutrition in the York River, Virginia. In: Wiley M (ed) Estuarine processes, Vol 1, Uses, stresses, and adaptation to the estuary. Academic Press, New York, p 90-102

Manuscript received: February 21, 1997

Revised version accepted: April 30, 1997 